Boyne, A. W., Campbell, R. M., Davidson, J. \& Cuthbertson, D. P. (1956), Br. F. Nutr. ro, 325.

Bruce, J., Goodall, E. D., Kay, R. N. B., Phillipson, A. T. \& Vowles, L. E. (1966). Proc. R. Soc. B 166,46 .

Clary, J. J., Mitchell, G. E. Jr \& Little, C. O. (1967). 7. Anim. Sci. 26, 917.

Clegg, K. M. (1956). J. Sci. Fd Agric. 7, 40.

Elsden, S. R., Hitchcock, M. W. S., Marshall, R. A. \& Phillipson, A. T. (1945-6). Ұ. exp. Biol. 22, I91.

Gray, F. V. (1947). F. exp. Biol. 24, 15.

Hale, E. B., Duncan, C. W. \& Huffman, C. F. (r947). F. Nutr. 34, 24 I.

Hassid, W. Z. \& Neufeld, F. (1964). In Methods in Carbohydrate Chemistry. Vol. 4, p. 33. [R, L. Whistler, editor.] New York: Academic Press Inc.

Heald, P. J. (195I). Br. 7. Nutr. 5, 84 .

Hembry, F. G., Bell, M. C. \& Hall, R. F. (r967). F. Nutr. 93, i 75 .

Hogan, J. P'. \& Weston, R. H. (1967). Aust. F. agric. Res. 18, 803 .

Huber, J. T., Jacobson, N. L., McGilliard, A. D. \& Allen, R. S. (1961). F. Dairy Sci. 44, 32 I.

Karr, M. R., Little, C. O. \& Mitchell, G. E. Jr (1966). Y. Anim. Sci. 25, 652.

Lennox, A. M. \& Garton, G. A. (1968), Br. F. Nutr. 22, 247.

Little, C. O., Mitchell, G. E. \& Reitnour, C. M. (1968). F. Anim. Sci. 27, 790.

Long, C. (editor). (1961). Biochemists Handbook, London: Spon.

MacRae, J. C. (1967). PhD Thesis, University of Newcastle upon Tyne.

MacRac, J. C. \& Armstrong, D. G. (1968). F. Sci. Fd Agric. 19, 578 .

MacRae, J. C. \& Armstrong, D. G. (I969). Br. F. Nutr. 23. (In the Press.)

Marshall, R. A. (r949). Br.F. Nutr. 3, I.

Mitchell, G. E. Jr, Little, C. O., Karr, M. R. \& Hayes, B. W. (1967). J. Anim. Sci. 26, 224.

MacKenzie, D. J. \& Wylam, C. B. (1957). F. Sci. Fd Agric. 8, $3^{8}$.

Morrison, F. B. (1959). Feeds and Feeding, 22nd ed, p. 416. Iowa: Morrison.

Myers, L. L., Jackson, H. D. \& Packett, L. V. (r967). F. Anim. Sci. 26, 1450.

Phillipson, A. T. (1952). F. Physiol., Lond. 116, 84 .

Porter, P. \& Singleton, A. G. (1965). Biochem. 7. 96, $59 \mathrm{P}$.

Rogerson, A. (1958), Br, F, Nutr, 12, 164.

Salo, M. L. (1965). Determination of Carbohydrate Fractions in Animal Foods and Faeces. Helsinki.

Siddons, R. C. (1968). Biochem. F. ro8, 839 .

Sutton, J. D. \& Nicholson, J. W. G. (1968). Proc. Nutr. Soc. 27, 49 A.

Thomson, D. J., Beever, D. E., Coehlo da Silva, J. F. \& Armstrong, D. G. (1969). Proc. Nutr. Soc. 28,24 A.

Topps, J. H., Kay, R. N. B. \& Goodall, E. D. (1968). Br. F. Nutr. 22, 26 r.

Topps, J. H., Kay, R. N. B., Goodall, E. D., Whitelaw, F. G. \& Reid, R. S. (I968). Br. F. Nutr. 22, 28 r.

Tucker, R. E., Mitchell, G. E. Jr \& Little, C. O. (1968). F. Anim. Sci. 27, 824.

Waite, R. \& Gorrod, A. R. N. (1959a). F. Sci. Fd Agric, ro, 308 .

Waite, R. \& Gorrod, A. R. N. (1959b). Y. Sci. Fd Agric. 1o, 3 I 7.

Waite, R., Johnston, M. J. \& Armstrong, D. G. (1964). F. agric. Sci., Camb. 62, 39 .

Weller, R. A. \& Gray, F. V. (1954). 7. exp. Biol. 3r, 40.

Wright, P. L., Grainger, R. B. \& Marco, G. J. (1966). F. Nutr. 89, 241.

\title{
Digestion and absorption of lipids in the ruminant
}

\section{By G. A. Garton, Rowett Research Institute, Bucksburn, Aberdeen}

Although this Symposium is concerned primarily with events in the abomasum and intestinal tract, it is necessary first to consider briefly the fate of dietary lipids in the reticulo-rumen since this has consequences which significantly affect the chemical and physical state of the lipids which pass on to the abomasum and small intestine. While many of the studies which are discussed refer to sheep, it is reasonable to suppose that the findings apply to ruminants in general. 
Studies in the past decade or so (reviewed by Garton, 1965, 1967) have shown that the micro-organisms in the rumen can effect extensive changes in dietary lipids. These changes include the hydrolytic release of esterified fatty acids and the hydrogenation of the double bonds of unsaturated fatty acids. Since the lipids of most common feeds (e.g. galactoglycerides of herbage, triglycerides of 'concentrates' of vegetable origin) have a high content of $\mathrm{C}_{18}$ unsaturated acids, microbial activity results in the accumulation of free stearic acid as the end-product of hydrogenation and of geometrical (trans) and positional isomers of oleic, linoleic and linolenic acids as the products of incomplete hydrogenation. Unlike pancreatic lipase, which does not remove fatty acids esterified to the secondary alcoholic group (2-position) of the glycerol molecule, rumen (bacterial) lipase activity is non-selective and so very little or no 2-monoglyceride is formed. The hydrolysis of glyceridic lipids usually goes fairly rapidly to completion in the rumen and the liberated glycerol is fermented to short-chain, water-soluble fatty acids which are absorbed across the rumen wall. Very little, if any, degradation of long-chain fatty acids apparently takes place in the rumen and there is no evidence that acids of chain length $\mathrm{C}_{16}$ and greater are absorbed to any appreciable extent from this part of the alimentary tract.

\section{Nature of the lipids in the jejumum}

Chemical state. The lipids which are present in the digesta passing more or less continuously from the rumen through the omasum and abomasum to the small intestine thus consist largely of free fatty acids (of which stearic acid is normally a major component), together with the structural lipids of the micro-organisms which accompany the digesta. The proportions of fatty acids contributed by each major lipid fraction to the total fatty acids present in different parts of the alimentary tract are exemplified in Table $I$ by the values for sheep fed on hay and concentrates (linseed meal and crushed oats).

Table x. Percentage proportions of the fatty acids contributed by the major lipid fractions to the total fatty acids in the alimentary tract of sheep fed on hay and concentrates

(Mean values of four animals: from results of Lennox, Lough \& Garton (1968))

\begin{tabular}{lccc}
\multicolumn{3}{c}{ Source of fatty acids } \\
Source of digesta & $\begin{array}{c}\text { Unesterified } \\
\text { fatty acids }\end{array}$ & Neutral lipids & Phospholipids \\
Rumen & $71 \cdot 5$ & $23 \cdot 6$ & $4 \cdot 9$ \\
Abomasum & $77 \cdot 1$ & $19 \cdot 7$ & $3 \cdot 2$ \\
Upper jejunum & $53 \cdot 4$ & $22 \cdot 1$ & $24 \cdot 5$
\end{tabular}

Though the fatty acids which are enzymically liberated in the rumen from feed lipids were referred to above as free fatty acids, the term unesterified fatty acids is to be preferred. This is because the acids, though readily extractable in the free state 
from the digesta by the use of suitable solvents, are present in close association with the particulate matter in the rumen and abomasum (cf. Ward, Scott \& Dawson, I964) and in the small intestine (see Table 6).

Very little change takes place in the relative proportions or fatty acid composition of the various classes of lipid present in the digesta during its passage through the abomasum (Bath \& Hill, I967), though here most of the micro-organisms disintegrate (Smiles \& Dobson, 1956), which probably facilitates the subsequent digestion of their structural lipids.

In the upper jejunum, however, the pattern of lipid distribution and composition changes; as Table I shows, the proportion of unesterified fatty acids is lower than that in the ruminal and abomasal digesta and there is a considerable increment to the fraction of fatty acids esterified in the form of phospholipids. This is due to the influx of biliary lipids, which have a high content of phospholipids consisting mostly of phosphatidylcholine (lecithin) together with some lysophosphatidylcholine (lysolecithin) and phosphatidylethanolamine (Table 2; Adams \& Heath, 1963; Leat, I965; Lennox, Lough \& Garton, 1965, 1968); pancreatic juice contains virtually no lipid (Leat, I 965 ). It was estimated by Adams \& Heath (I963) that some IO-I $5 \mathrm{~g} /$ day of biliary phospholipids enter the small intestine of the adult sheep.

\section{Table 2. Lipid constituents of gall-bladder bile of the sheep and the ox}

(Pooled samples from six animals of each species; values of Lennox et al. (1968) and unpublished observations)

\begin{tabular}{lcc}
\multicolumn{1}{c}{ Lipid } & Shount (mg/roo $\mathrm{ml}$ bile) & $\mathrm{Ox}$ \\
Unesterified fatty acids & 46 & I5 \\
Neutral lipids* & I 44 & 67 \\
Phospholipids & I 48 & 868 \\
Lecithin & I I7 & 40 \\
Lysolecithin & 44 & 43 \\
Phosphatidylethanolamine & *Mainly sterols and sterol esters.
\end{tabular}

The admixture of biliary lipids with those in the chyme entering the small intestine is reflected in the fatty acid composition of the phospholipids and unesterified fatty acids present in upper jejunal contents. Bile phospholipids contain significant proportions of $\mathrm{C}_{18}$ unsaturated fatty acids (Table 3 ) and, as the typical analyses given in Table 4 show, the phospholipids and unesterified fatty acids from the upper jejunum have a higher content of these acids than do the corresponding fractions of ruminal lipids; the increment to the unesterified fatty acids is apparently mainly due to the hydrolysis of some biliary lecithin occasioned by pancreatic phospholipase activity (cf. Leat, 1965 ). Though bile contributes in some measure to the neutral lipids in the jejunum, these are also derived from the lipids of rumen micro-organisms. 
Table 3. Proportions of $C_{18}$ fatty acids in the phospholipids and unesterified fatty acids of sheep bile.

(Values as \% by weight of total fatty acids in each lipid; Lennox et al. 1968)

\begin{tabular}{|c|c|c|c|c|}
\hline \multirow[b]{2}{*}{ Fatty acid } & \multicolumn{3}{|c|}{ Phospholipids } & \multirow[b]{2}{*}{$\begin{array}{l}\text { Unesterified } \\
\text { fatty acids }\end{array}$} \\
\hline & Lccithin & Lysolecithin & $\begin{array}{l}\text { Phosphatidyl- } \\
\text { ethanolamine }\end{array}$ & \\
\hline 18:0 & $9^{\prime} \mathbf{I}$ & $9 \cdot 6$ & $27 \cdot 8$ & I $8 \cdot 5$ \\
\hline $18: 1$ & 30.7 & $35^{\circ} \mathrm{I}$ & 28.9 & $26 \cdot 6$ \\
\hline $18: 2$ & $6 \cdot 9$ & $6 \cdot 9$ & $5 \cdot 8$ & $12 \cdot 1$ \\
\hline $18: 3$ & $7 * 4$ & $6 \cdot 2$ & 4.3 & $8 \cdot 7$ \\
\hline
\end{tabular}

Table 4. Proportions of palmitic acid (I6:0) and $C_{18}$ fatty acids in the unesterified fatty acids and phospholipids in the rumen and upper small intestine of a sheep fed on hay and concentrates

(Values as $\%$ by weight of total fatty acids in each class of lipid)

\begin{tabular}{|c|c|c|c|c|}
\hline \multirow[b]{2}{*}{ Fatty acid } & \multicolumn{2}{|c|}{ Unesterified fatty acids } & \multicolumn{2}{|c|}{ Phospholipids } \\
\hline & Rumen & Intestine & Rumen & Intestine \\
\hline$I 6: 0$ & 10.3 & $14 \cdot 2$ & $40 \cdot 3$ & $2 \mathrm{I} \cdot 5$ \\
\hline 18:0 & $78 \cdot 0$ & $54^{-9}$ & I 3.7 & $45 \cdot 7$ \\
\hline 18:I & $x=7$ & 15.5 & $8 \cdot 2$ & $16 \cdot 6$ \\
\hline $18: 2$ & Trace & 4.0 & 6.0 & $6 \cdot 8$ \\
\hline $18: 3$ & Trace & 4.0 & Trace & $3 \cdot 0$ \\
\hline
\end{tabular}

The lipid constituents, conjugated bile salt content and $\mathrm{pH}$ of representative samples of digesta obtained from three sheep with cannulas in different parts of the jejunum (Lennox et al. 1968 ) are given in Table 5.

Table 5. Lipid components, bile salts and $p H$ of the jejunal contents of three cannulated sheep fed on dried grass

(Values as $\mathrm{mg} / \mathrm{ro0} \mathrm{ml}$ digesta)

\begin{tabular}{|c|c|c|c|}
\hline \multirow[b]{2}{*}{ Constituent } & \multicolumn{3}{|c|}{$\begin{array}{c}\text { Distance }(\mathrm{m}) \text { of cannula distal } \\
\text { to bile duct }\end{array}$} \\
\hline & 0.5 & $2 \cdot 0$ & $8 \cdot 0$ \\
\hline Conjugated bile salts & 536 & 993 & 2357 \\
\hline Neutral lipids & 128 & I I I & I 68 \\
\hline Unesterified fatty acids & $13^{8}$ & 179 & $8_{5}$ \\
\hline Phospholipids & & & \\
\hline Lecithin & 28 & 19 & None \\
\hline Lysolecithin & Io & 37 & None \\
\hline pH & 4.0 & $5^{\prime 2}$ & $8 \cdot 0$ \\
\hline
\end{tabular}

The respective cannulas allowed samples to be taken from the proximal jejunum (i.e. at a point just distal to the entry of the common bile duct) and from the upper jejunum and the terminal jejunum (about the mid-point of the small intestine). 
Whereas, owing to the absorption of water, the values for the content of conjugated bile salts increased progressively with increasing distance of the cannula from the bile duct, the values for unesterified fatty acids and neutral lipids showed no similar trend, indicating (vide infra) that the former are absorbed from the jejunum and that the latter are also absorbed and/or hydrolysed. The relative amounts of the two phospholipids show differences which are consistent with the progressive formation of lysolecithin from lecithin as the chyme moves along the jejunum (cf. Leat \& Harrison, 1967, 1969).

Physical state. The unesterified fatty acids entering the small intestine are closely associated with the particulate matter of the digesta, and in addition, a considerable part (about two-thirds) of the phospholipids of biliary origin and about $40 \%$ of the conjugated bile salts are also present in the solid phase of the chyme of the upper jejunum (Table 6, from Lennox et al. I968; cf. Leat \& Harrison, r 969). As far as the total unesterified fatty acids and total bile salts in the digesta are concerned, the extent of their association with the particulate matter persists into the terminal jejunum.

Table 6. Proportions of lipids and bile salts associated with the solid phase of the jejunal digesta of two sheep fed on dried grass

\begin{tabular}{clc}
$\begin{array}{c}\text { Distance }(\mathrm{m}) \text { distal } \\
\text { to bile duct }\end{array}$ & \multicolumn{1}{c}{ Constituent } & $\%$ \\
$2 \cdot 0$ & Conjugated bile salts & 39 \\
& Unesterified fatty acids & 93 \\
& Lecithin & 74 \\
& Lysolecithin & 62 \\
$8 \cdot 0$ & Conjugated bile salts & 42 \\
& Unesterified fatty acids & 92
\end{tabular}

Details of composition of whole digesta are given in Table 5 .

It is not yet known whether the biliary components of the solid phase are present in adsorbed form (as the unesterified fatty acids apparently are) or, owing to the low $\mathrm{pH}$ conditions in the upper jejunum (see Table 5 ), are merely precipitated from solution. In this context it may be of relevance to note that Eastwood \& Boyd ( 1967 ) have observed that, in the lumen of the small intestine of the rat, bile salts are distributed between the solid and aqueous phases of the digesta. Iignin is apparently mainly responsible for the adsorption of bile salts and this is maximal under acidic conditions (Fastwood \& Hamilton, r968).

The aqueous phase of the intestinal chyme of the ruminant consists of a micellar solution of conjugated bile salts which includes small amounts of lecithin, lysolecithin and unesterified fatty acids; no 'oily' phase, similar to that found in the jejunum of non-ruminant animals, is present.

\section{Absorption of lipids}

Some quantitative aspects of lipid digestion, particularly in relation to $\mathrm{C}_{18}$ fatty acids, which normally predominate in the digesta, will first be considered. Paul \& 
McCay (I943) noted that more than $90 \%$ of the fatty acids of chemically-hydrogenated cottonseed oil were absorbed by sheep when the oil formed $6 \%$ of the feed, and Balch, Balch, Bartlett, Johnson \& Rowland (1952) found that, for cows fed on hay and concentrates, about $83 \%$ of the lipids were digestible. The amount of $\mathrm{C}_{18}$ fatty acids excreted daily by sheep fed on hay and oats was calculated by Ward et al. (1964) to be about $11 \%$ of the dietary intake, and Czerkawski, Blaxter \& Wainman (1965) reported no marked faecal loss of energy in sheep given daily intra-ruminal infusions of up to $88 \mathrm{~g} \mathrm{C}_{18}$ unsaturated acids for periods of more than 3 weeks. These results imply that, in contrast to the poor digestibility of stearic acid in non-ruminants (Carroll \& Richards, $195^{8}$ ), this acid is fairly readily assimilated from the small intestine of the ruminant.

This conclusion is supported by the work of Lennox \& Garton (I968), who studied quantitative aspects of lipid absorption in more detail by using sheep each fitted with two pairs of re-entrant cannulas in different parts of the small intestine from the upper jejunum to the terminal ileum. The animals were fed on dried grass cubes or on hay, linseed meal and oats and samples of digesta were analysed for their content of unesterified fatty acids, neutral lipids and phospholipids, and the contribution of each fraction to the total fatty acids was calculated; polyethylene glycol was infused into the rumen, and its content in the digesta afforded a measure of the extent to which water had been absorbed. It was found that by the time the digesta reached the terminal jejunum (i.e. half way along the small intestine) the uptake of unesterified fatty acids was almost complete, as was also the hydrolytic release of esterified fatty acids.

About $80 \%$ of the total fatty acids entering the upper jejunum in the digesta and bile $(400-500 \mathrm{mg} / \mathrm{h})$ was absorbed mostly from the middle and lower jejunum where the $\mathrm{pH}$ ranged from about $4^{\circ} \mathrm{O}$ to between $7^{\circ} \mathrm{O}$ and $8 \cdot 0$; some absorption, mainly of unesterified fatty acids, took place in the upper small intestine where the $\mathrm{pH}$ was between 2.5 and $4 \cdot 0$. The hydrolysis and/or uptake of esterified fatty acids took place mainly in the middle and lower jejunum (Table 7 ).

Table 7. Proportions of fatty acids remaining in ester combination following passage of digesta through different parts of the jejunum of sheep

\begin{tabular}{|c|c|c|c|}
\hline \multirow[b]{2}{*}{$\begin{array}{l}\text { Part and length } \\
\text { of small intestine }\end{array}$} & \multirow[b]{2}{*}{ Diet } & \multicolumn{2}{|c|}{$\begin{array}{c}\text { Proportion }(\%) \text { remaining } \\
\text { esterified as }\end{array}$} \\
\hline & & $\begin{array}{l}\text { Neutral } \\
\text { lipid }\end{array}$ & $\begin{array}{l}\text { Phospho- } \\
\text { lipid }\end{array}$ \\
\hline Upper jejunum & Hay and concentrates & 88 & 87 \\
\hline$(2.0 \mathrm{~m})$ & Grass cubes & 75 & 89 \\
\hline Middle and lower & Grass cubes & 50 & 8 \\
\hline jejunum $(6.0 \mathrm{~m})$ & Grass cubes & 29 & 17 \\
\hline
\end{tabular}

Though there were no gross differences in over-all composition of either the total unesterified fatty acids or total esterified fatty acids in different parts of the small intestine, the uptake of unesterified fatty acids was not completely unselective. From 
the major components (palmitic acid, stearic acid and $\mathrm{C}_{18}$ mono-unsaturated acid) there was a somewhat preferential uptake of the unsaturated acid, notably of that possessing the trans configuration (cf. Ward et al. 1964).

As judged by the amounts of lipid present in lymph draining the intestine of the sheep, lipid absorption is considerably reduced in animals deprived of pancreatic juice and is almost completely abolished in the absence of bile (Heath \& Morris, 1963). It is necessary to consider the role of these secretions in promoting lipid absorption in the ruminant in the light of recent studies (reviewed by Senior ( 1964 ) and Hofmann ( 1966$)$ ) on lipid digestion in non-ruminant animals. This work has strongly indicated that the uptake of long-chain fatty acids from the small intestine is dependent on their being rendered soluble in the form of mixed micelles with conjugated bile salts. This solubilization of fatty acids in bile salt micelles is promoted by ( $\mathbf{I}$ ) the presence of monoglycerides (derived from the action of pancreatic lipase on triglycerides) which expand the micellar structure and (2) partial ionization of the fatty acids which occurs at a $\mathrm{pH}$ of about 6.5 in the upper jejunum of the non-ruminant. It is reasonable to suppose that micellar solubilization of long-chain fatty acids is also a prerequisite for their absorption from the jejunum of the ruminant, though it has been shown that monoglyceride is absent from the chyme and that absorption can take place when the $\mathrm{pH}$ in the intestinal lumen is much lower than $6 \cdot 5$.

The function of pancreatic juice, other than as a source of bicarbonate contributing to the neutralization of gastric hydrochloric acid, appears to be that of providing phospholipase responsible for the production of lysolecithin. The lysolecithin may well expand the micelles of conjugated bile salts in a similar manner to monoglyceride in the gut of the non-ruminant animal and thus account for the solubilization of long-chain fatty acids when they are partly ionized (i.e. at about $\mathrm{pH} 6.5$ or greater), though it does not offer an explanation for the solubilization which presumably takes place before fatty acids are absorbed from the upper jejunum where much lower $\mathrm{pH}$ values prevail.

The release of fatty acids and also of biliary lipids and conjugated bile salts from their association with particulate matter is a phenomenon which is apparently peculiar to the ruminant small intestine and which has not yet been investigated in any detail. It has been found in preliminary studies (Scott \& Lough, unpublished) that, in vitro at $37^{\circ}$ and $\mathrm{pH} 4.0$, the addition of whole bile to sheep duodenal contents will effect a considerably greater degree of solubilization of the adsorbed fatty acids than can be effected by bile salts alone, suggesting that some other biliary constituent (e.g., intact lecithin) may be of significance in promoting desorption and the formation of a micellar solution with conjugated bile salts (cf. discussion by Small ( 1968 ) of the system lecithin-bile salts-water as a milieu for the solubilization of insoluble, amphiphilic substances such as un-ionized long-chain fatty acids).

Whatever the mechanism by which lipids are solubilized, it is evident from the results of Lennox \& Garton (I968) that only a very small fraction of the total fatty acids is available for absorption from the jejunum at any given time. With respect to esterified fatty acids, it is possible that some lysolecithin may be absorbed intact, 
and in this connexion it is of interest to note that Nilsson \& Borgström (1967) found that, whereas lecithin was not absorbed by intestinal slices of hamsters and rats, lysolecithin was readily assimilated and acylated (see also Nilsson, x968).

In the ruminant, conjugated bile salts are probably absorbed by an active process from the lower small intestine as in non-ruminant animals (see, for example, Lack $\&$ Weiner (1963) and Gordon \& Kern (1968)).

\section{Fate of absorbed lipids in the intestinal mucosa}

The end-products of mucosal metabolism of the fatty acids and of other lipids which may be absorbed from the small intestine are the lymph (chylomicron) lipids; these have been investigated in sheep with cannulas in the intestinal lymph duct or the thoracic duct (Lough, Feliński \& Garton, 1963; Feliński, Garton, Lough \& Phillipson, 1964; Heath, Adams \& Morris, 1964) and in cows with thoracic duct cannulas (Hartmann \& Lascelles, 1966; Wadsworth, 1968). As in non-ruminant animals, the chylomicron lipids consist of $70-80 \%$ triglyceride, $15-20 \%$ phospholipid and small amounts of cholesterol, cholesterol esters and unesterified fatty acids. For sheep fed on hay and concentrates the total amount of lipid in daily transport

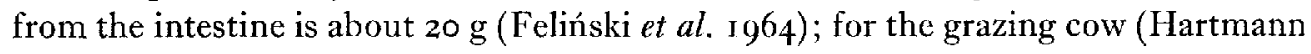
$\&$ Lascelles, 1966) the amount is between $200 \mathrm{~g}$ (non-lactating animals) and $400 \mathrm{~g}$ (lactating animals). The fatty acid composition of the two major classes of lymph lipid is shown in Table 8.

Table 8. Major component fatty acids of the triglycerides and phospholipids in transport from the small intestine of the sheep and the ox (Values as \% by weight of total fatty acids in each class of lipid; from values of
Feliński et al. (1964) and Wadsworth (1968))

\begin{tabular}{|c|c|c|}
\hline \multirow{3}{*}{ Fatty acid } & \multicolumn{2}{|c|}{ Source of fatty acids } \\
\hline & Triglycerides & Phospholipids \\
\hline & \multicolumn{2}{|c|}{ Sheep* thoracic-duct lymph } \\
\hline $16: 0$ & $14 \cdot 2$ & $18 \cdot 2$ \\
\hline $18: 0$ & 45.1 & $23 \cdot 8$ \\
\hline 18:1 & $2 \mathbf{r} \cdot 9$ & $16 \cdot 2$ \\
\hline $18: 2$ & $4 \cdot 8$ & 20.2 \\
\hline $18: 3$ & $4 \cdot 5$ & $8 \cdot 4$ \\
\hline \multicolumn{3}{|c|}{ Ox† thoracic-duct lymph } \\
\hline $16: 0$ & $22 \cdot 3$ & $16 \cdot 7$ \\
\hline 18:0 & $42 \cdot 9$ & $28 \cdot 3$ \\
\hline $18: 1$ & 14.8 & $12 \cdot 5$ \\
\hline $18: 2$ & $2 \cdot 5$ & 23.9 \\
\hline $18: 3$ & 3.0 & $7 \cdot 9$ \\
\hline \multicolumn{3}{|c|}{$\begin{array}{l}\text { *Diet: hay and concentrates. } \\
\text { †Diet: pasture and concentrates. }\end{array}$} \\
\hline
\end{tabular}

With respect to the triglycerides, the composition resembles that of the unesterified fatty acids of the jejunal lumen (Table 4 ) and is characterized by the high 
proportion of stearic acid. Though it has been reported (Bickerstaffe \& Annison, I968) that stearic acid can be desaturated to give oleic acid by preparations of sheep intestinal epithelium, it does not seem that in vivo this process is quantitatively very significant. The source of glyceride-glycerol is evidently endogenouslyproduced $\alpha$-glycerophosphate, the conversion of which into triglycerides by intestinal mucosal tissue takes place by a well-established series of reactions (Johnston, 1963; Senior, 1964). As a result of this synthesis stearic acid is preferentially esterified to the primary alcoholic groups (positions 1 and 3 ) of the glycerol moiety of sheep lymph triglycerides (Garton \& Duncan, 1965).

Compared with the triglycerides, the fatty acids of the lymph phospholipids (mainly lecithin) contain notably higher proportions of $\mathrm{C}_{18}$ di- and tri-unsaturated acids accompanied by a correspondingly lower proportion of stearic acid. Though the origin of these phospholipids has not yet been established it could well be that, in part at least, they represent the products of acylation of lysolecithin absorbed intact from the jejunal lumen.

\section{REFERENCES}

Adams, E. P. \& Heath, 'I'. J. (1963). Biochim. biophys, Acta 7o, 688.

Balch, C. C., Balch, D. A., Bartlett, S., Johnson, V. W. \& Rowland, S. J. (1952). Br. F. Nutr. 6, 356. Bath, I. H. \& Hill, K. J. (1967). F. agric. Sci., Camb. 68, 139.

Bickerstaffe, R. \& Annison, E. F. (1968). Biochem. F. 107, 27 P.

Carroll, K. K. \& Richards, J. F. (1958). F. Nutr. 64, 4 I I.

Czerkawski, J. W., Blaxter, K. L. \& Wainman, F. W. (1965). Proc. Nutr. Soc. 24, xvii.

Eastwood, M. A. \& Boyd, G. S. (1967). Biochim. biophys. Acta ז37, 393.

Eastwood, M. A. \& Hamilton, D. (1968). Biochim. biophys. Acta 152, 165.

Feliński, L., Garton, G. A., Lough, A. K. \& Phillipson, A. T. (1964). Biochem. Y. 90, 54.

Garton, G. A. (1965). In Physiology of Digestion in the Ruminant, p. 390. [R. W. Dougherty, editor.] Washington, D.C.: Butterworths.

Gatton, G. A. (1967). Wld Rev. Nutr. Diet. 7, 225.

Garton, G. A. \& Duncan, W. R. H. (1965). Biochim. biophys. Acta 98, 436 .

Gordon, S. G. \& Kern, F. Jr ( 1968). Biochim. biophys. Acta 152, 372.

Hartmann, P. E. \& Lascelles, A. K. (1966). I. Physiol., Lond. 184, 193.

Heath, T. J. \& Morris, B. (1963). Br. $\mathcal{F}$. Nutr. 17, 465.

Heath, T. J., Adams, E. P. \& Morris, B. (1964). Biochem. $7.92,51$ I.

Hofmann, A. F. (1966). Gastroenterology 50, 56 .

Johnston, J. M. (1963). In Advances in Lipid Research. Vol. I, p. I05. [R. Paoletti and D. Kritchevsky, editors.] New York and London: Academic Press Inc.

Lack, L. \& Weiner, I. M. (1963). Fedn Proc. Fedn Am. Socs exp. Biol. 22, I334.

Leat, W. M. F. (1965). Biochem. 7. 94, 2rP.

Leat, W. M. F. \& Harrison, F. A. (1967). Biochem. F. ro5, г3P.

Leat, W. M. F. \& Harrison, F. A. (1969). Q. Fl exp. Physiol. (In the Press.)

Lennox, A. M. \& Garton, G. A. (1968). Br. F. Nutr. 22, 247.

Lennox, A. M., Lough, A. K. \& Garton, G. A. (1965). Biochem. F. 96, 27P.

Lennox, A. M., Lough, A. K. \& Garton, G. A. (1968). Br. F. Nutr. 22, 237.

Lough, A. K., Felinski, L. \& Garton, G. A. (r963). In Biochemical Problems of Lipids, p. 264. [A. C. Frazer, editor.] Amsterdam: Elsevier.

Nilsson, A. (1968). Biochim. biophys. Acta r52, 379.

Nilsson, A. \& Borgström, B. (1967). Biochim. biophys. Acta 137, 240.

Paul, H. \& McCay, C. M. (1943). Archs Biochem. I, 247.

Senior, J. R. (1964). J. Lipid Res. 5, 495.

Small, D. M. (1968). f. Am. Oil Chem. Soc, 45, 108.

Smiles, J. \& Dobson, M. J. (1956). Il R. microsc. Soc. 75, 244.

Wadsworth, J. C. (1968). F. Dairy Sci. 51, 876.

Ward, P. F. V., Scott, T. W. \& Dawson, R. M. C. (1964). Biochem. F. 92, 60. 